Chara Bakalis

The Victims of Hate Crime and the Principles of the Criminal Law, Legal Studies (forthcoming)

DOI: tbc

This version is available: https://radar.brookes.ac.uk/radar/items/3bbda07c-0f52-450a-a085-6f9fd1f5c1b1/1/

Available on RADAR: 07.03.2017

Copyright (c) and Moral Rights are retained by the author(s) and/ or other copyright owners. A copy can be downloaded for personal non-commercial research or study, without prior permission or charge. This item cannot be reproduced or quoted extensively from without first obtaining permission in writing from the copyright holder(s). The content must not be changed in any way or sold commercially in any format or medium without the formal permission of the copyright holders.

This document is the author's final accepted manuscript. 


\section{The Victims of Hate Crime and the Principles of the Criminal Law}

\section{Abstract}

There is an ongoing debate amongst hate crime scholars about the categories of victims which should be included within hate crime legislation. Some commentators argue that affording protection to groups based on pre-defined characteristics results in many victims being excluded from the legislation. They would prefer a more inclusive approach which would offer protection to a potentially limitless number of groups. This paper considers the question from a doctrinal perspective, and argues that a principled way of deciding the characteristics of hate crime is required. It will conclude that the core concern of hate crime legislation is with the furthering of the broader equality agenda and, as such, the victims of hate crime should form an exclusive group based on those characteristics protected under equality legislation. This approach can help provide a theoretical framework for hate crime legislation which can be more easily accommodated within criminal law principles.

\section{Introduction}

The term 'hate crime' does not have a specific legal meaning, but has been used flexibly to describe any legislation or legal response aimed at punishing criminal behaviour which demonstrates either hatred, or hostility or bias towards a particular group in society. In this paper, hate crime will be used to refer to the offences encompassed by three main pieces of legislation: the aggravated offences under the Crime and Disorder Act 1998, the stirring up offences under the Public Order Act 1986, and the enhanced sentencing provisions under the Criminal Justice Act 2003.

Under sections 28-32 of the Crime and Disorder Act 1998 (hereafter, 'CDA'), an aggravated offence is committed when a defendant demonstrates or was motivated by hostility 
towards a person on the grounds of race and religion ${ }^{1}$ in the course of committing a 'basic offence' such as assault or criminal damage. ${ }^{2}$ The aggravated offence attracts a higher penalty than the basic offence. ${ }^{3}$

The stirring up offences under the Public Order Act 1986 (hereafter 'POA') have a long history ${ }^{4}$ rooted in anti-discrimination legislation, but in their current form they seek to criminalise behaviour which is threatening, abusive or insulting where there is an intention to thereby stir up racial hatred, or, having regard to all the circumstances, racial hatred was likely to be stirred up thereby. ${ }^{5}$ These offences were extended in 2007 to include the stirring up of religious hatred, and in 2010, a further extension was implemented to include sexual orientation, thus incorporating a characteristic not currently present under the CDA. ${ }^{6}$

The most extensive classification of characteristics can be found under s. 145 and s. 146 of the Criminal Justice Act 2003 (hereafter 'CJA'), which requires sentencing judges to take account of hostility on the basis of race, religion, sexual orientation, disability or transgender identity as an aggravating factor in sentencing. This requirement applies to sentencing for all crimes, and is not limited to a small number of offences as is the case under the CDA. However, unlike the CDA, the aggravation cannot result in a sentence that is higher than the ordinary statutory maximum, and the fact of aggravation does not appear in the name of the offence for which the offender has been found guilty.

\footnotetext{
${ }^{1}$ Aggravated offences in relation to racial hostility were enacted under the Crime and Disorder Act 1998, ss 28-32, and racially aggravated offences were added by the Anti-terrorism, Crime and Security Act 2001, s 39.

${ }^{2}$ The other basic offences are certain public order offences involving threatening, abusive or insulting conduct, harassment or stalking and putting people in fear of violence.

${ }^{3}$ For example, the maximum for the basic offence of s. 20 of the Offences Against the Person Act 1861 is 5 years, but this is increased to 7 years under the CDA.- Crime and Disorder Act 1998, s 29(2)(b).

${ }^{4}$ See for instance, G Schaffer, 'Legislating against Hatred: Meaning and Motive in Section Six of the Race Relations Act of 1965' (2014) 25 Twentieth Century British History and I Hare, 'Legislating Against Hate - The Legal Response to Bias Crimes' (1997) 17 OJLS 415.

5 There are several types of behaviour that fall into this category, including the possession, display, publication or distribution of written material or visual images or sound, or presenting or directing the public performance of a play - Public Order Act 1986, ss 18-22.

${ }^{6}$ The offences were extended to 'religion' by the Racial and Religious Hatred Act 2006, and to 'sexual orientation' by the Criminal Justice and Immigration Act 2008.
} 
Although the umbrella term 'hate crime' is used to refer to these provisions, they were enacted at separate times, and have developed discretely and independently of each other. The variation in the type of characteristics which are included in the different pieces of legislation reflects the organic way in which hate crime law has developed over the last two decades. In 2013, the Ministry of Justice invited the Law Commission to reflect on this disparity and asked them to consider the case for extending the CDA and POA offences to bring them into line with the characteristics currently covered by the CJA. ${ }^{7}$ This desire to extend the characteristics of hate crime forms part of the Government's Hate Crime agenda ${ }^{8}$, and so, therefore, is clearly policy based. However, although such policy-driven proposals are an inevitable characteristic of law reform, the case for extension needs to be grounded in a more principled rationale which can provide a framework for identifying which groups should be covered by hate crime legislation. The decision to extend hate crime provisions needs to be founded on a clear justification which gives due regard to the theoretical underpinnings of the criminal law, and must correlate with the function and purpose of hate crime legislation.

The need for a principled approach becomes apparent when we consider the number of different groups that could potentially be given protection under the legislation. Within the hate crime community, there is an ongoing debate about which victims should be covered by hate crime statutes. ${ }^{9}$ Although the type of victim included in hate crime legislation across the world varies according to the particular needs of each jurisdiction, ${ }^{10}$ there is a consensus around race,

\footnotetext{
${ }^{7}$ For details and analysis of the Law Commission's recommendations see C Bakalis, 'Legislating Against Hatred: The Law Commission's Report on Hate Crime' (2015) Crim LR 177.

${ }^{8}$ Details of the Action Plan can be found at: <www.gov.uk/government/publications/hate-crime-action-planchallenge-it-report-it-stop-it> accessed 15 January 2016.

${ }^{9}$ See for example: M Blake, 'Geeks and monsters: Bias crimes and social identity' (2001) 20 Law and Philosophy 121; R Grattet and V Jenness, 'Examining the Boundaries of Hate Crime Law: Disabilities and the "Dilemma of Difference"" in B Perry (ed.), Hate and Bias Crime: A Reader (Routledge, 2003) 284; N Chakraborti and J Garland, 'Reconceptualizing hate crime victimization through the lens of vulnerability and "difference" (2012) 16 Theoretical Criminology 499; J Schweppe 'Defining characteristics and politicizing victims: A legal perspective' (2012) 10 Journal of Hate Studies 173; M Al-Hakim, 'Making a home for the Homeless in Hate Crime Legislation' (2014) Journal of Interpersonal Violence 1; G Mason, 'Victim attributes in hate crime law: Difference and the politics of justice' (2014) 54 British Journal of Criminology 161. See also F M Lawrence Punishing Hate: Bias Crimes Under American Law (Harvard University Press 1999) 11-20.

${ }^{10}$ For examples see OSCE/ODIHR 'Hate Crime Laws: A Practical Guide’ (2009) 37, 38.
} 
national origin, ethnicity and religion, and to a lesser extent sexual orientation, age, gender and disability. ${ }^{11}$ However, it is clear that in spite of the agreement on this core, there is scope for extending beyond this to include characteristics such as "personal appearance"12 or 'any social group ${ }^{\prime 13}$. Some jurisdictions, such as Spain and Croatia have more open-ended definitions of protected characteristics by incorporating a level of flexibility within the legislation which permits judges to extend the categories as they see fit. ${ }^{14}$

This disagreement over the selection of victims has led some commentators to criticise the standard approach (which identifies victims by their characteristics) because it creates 'hierarchies of hate'. ${ }^{15}$ This occurs because, typically, only those groups with the ability to mobilise and organise themselves to achieve the necessary political clout to ensure inclusion in hate crime legislation are afforded the extra protection and attention which recognition in hate crime statutes provides. Chakraborti and Garland have argued that instead of putting identity and group membership at the heart of hate crimes, we should instead be focusing on the 'vulnerability' of victims, and the problems of 'difference.. ${ }^{16}$ By contrast, Al-Hakim is wary of using 'vulnerability' as a basis for allocating hate crime protection because he believes it emphasises the weakness or helplessness of the victim, and so he would favour an approach based on 'disadvantage' as that would better capture the moral wrong at the heart of hate crimes. ${ }^{17}$ Schweppe is also in favour of a more open definition for the victims of hate crime and recommends the jury should be given discretion to convict defendants whenever it can be shown that they exhibited hostility towards a victim because of their personal characteristics which they

\footnotetext{
${ }^{11}$ For examples see OSCE/ODIHR 'Hate Crime Laws: A Practical Guide' (2009) 37, 40.

12 Under section 22-3701 of the District of Columbia Code.

13 Under Article 63 of the Russian Criminal Code.

${ }^{14}$ OSCE/ODIHR 'Hate Crime Laws: A Practical Guide' (2009) 46.

${ }^{15} \mathrm{~N}$ Chakraborti and J Garland, 'Reconceptualizing hate crime victimization through the lens of vulnerability and "difference" (2012) 16 Theoretical Criminology 499, 499.

${ }^{16} \mathrm{~N}$ Chakraborti and J Garland, 'Reconceptualizing hate crime victimization through the lens of vulnerability and "difference”" (2012) 16 Theoretical Criminology 499.

${ }^{17} \mathrm{M}$ Al-Hakim, 'Making a home for the Homeless in Hate Crime Legislation' (2014) Journal of Interpersonal Violence 1.
} 
share with an identifiable social group. ${ }^{18}$ This will be referred to as 'group hostility'. These approaches would effectively make it possible for a large, if not limitless, number of groups to find protection under the legislation. Other commentators, such as Mason, although broadly in favour of a more inclusive approach, caution against a law that sets no limits to the category of victim. ${ }^{19}$ By allowing such a broad category of victimhood, it has been possible in New South Wales for legislation to be interpreted as giving protection to paedophiles, and thus give the impression that the state endorses and sanctions conduct that is illegal and intolerable to society. ${ }^{20}$ She argues, therefore, that any extension of the characteristics of victims must be 'tethered to a politics of justice that limits attributes to forms of difference that have a justifiable claim to affirmation, equality and respect for the attribute that makes them different'. ${ }^{21}$

It is important at the outset to recognise that this debate conflates two separate but interconnected issues. The first is to do with what rationale we should adopt to decide who the victims of hate crime should be. The above discussion shows that various options are possible such as 'difference' or 'vulnerability' or 'group hostility' or 'disadvantage' or, as will be argued in this article, 'equality'. The second issue concerns what should be done once the rationale for victimhood has been established - should the identities be 'exclusive' or 'inclusive'? An exclusive approach would require the victims (on whichever basis they have been decided) to be chosen in advance by legislation which names them specifically. An inclusive approach would give discretion to a judge or jury to decide in each case that comes before it whether the particular victim fell into the general category of hate crime victimhood. It is important to distinguish these two facets of the debate as it is wrong to assume that any particular rationale for hate crime is necessarily more inclusive than another. For example, Chakraborti and Garland

\footnotetext{
18 J Schweppe 'Defining characteristics and politicizing victims: A legal perspective' (2012) 10 Journal of Hate Studies 173.

${ }^{19} \mathrm{G}$ Mason, 'Victim attributes in hate crime law: Difference and the politics of justice' (2014) 54 British Journal of Criminology 161.

${ }^{20} \mathrm{G}$ Mason, 'Victim attributes in hate crime law: Difference and the politics of justice' (2014) 54 British Journal of Criminology 161.

${ }^{21}$ G Mason, 'Victim attributes in hate crime law: Difference and the politics of justice' (2014) 54 British Journal of Criminology 161.
} 
argue in favour of 'vulnerability' or 'difference' on the basis that these are inherently more inclusive than the current system which specifies in advance which groups are granted hate crime victimhood. However, 'vulnerability' or 'difference' as categories of hate crime are only more inclusive if discretion is given to judges or juries to determine in each case whether a victim belongs to a 'vulnerable' or sufficiently 'different' group. 'Vulnerability' can potentially be just as exclusive as the current approach if legislators were to decide in advance which groups have a vulnerable enough status to be covered by hate crime legislation.

This article aims to contribute to the first question of this debate by adopting a doctrinal analysis of hate crime legislation. .The second question on 'inclusivity' versus 'exclusivity' will be commented on in passing, but will not form the core of this piece. Whilst a number of commentators have tracked the political development of hate crime laws, ${ }^{22}$ less emphasis has been placed on the legal doctrinal issues. ${ }^{23}$ A doctrinal approach is necessary to ensure that the legislation - which has evolved as a result of a multitude of political pressures over the last fifty years - has a robust and compelling basis in criminal law doctrine. The principles of the criminal law exist in order to give legitimacy to the actions of the state; our hate crime legislation needs to have a firm foundation in such principles in order to be valid exercises in state power. This piece will take as its starting point basic criminal law values such as the need to identify the 'harm' or 'wrong' at the heart of hate crime legislation and the principle of 'minimum criminalisation'. It

There is a rich literature on the political dimension of hate crime laws. J B Jacobs and K Potter, Hate Crimes: Criminal Law and Identity Politics (OUP 1998) is a good starting point. A non-exhaustive list of other pieces includes: E MClaughlin, 'Rocks and hard places: The politics of hate crime' (2002) 6 Theoretical Criminology 493, L Moran 'Affairs of the heart: Hate crime and the politics of crime control' (2001), 12 Law and Critique 331-344, M Duggan and V Heap Administrating victimization: The politics of anti-social behaviour and hate crime policy (Palgrave Macmillan, 2014), J Garland and J Treadwell 'The New Politics of Hate? An Assessment of the Appeal of the English Defence League Amongst Disadvantaged White Working Class Communities in England' (2012) 10 Journal of Hate Studies 123.

\footnotetext{
${ }^{23}$ Notable exceptions are K Goodall, 'Conceptualising "racism” in the Criminal Law' (2013) 33 Legal Studies 215, M Walters 'Conceptualizing 'bostility' for hate crime law: minding 'the minutiae' when interpreting section 28(1)(a) of the Crime and Disorder Act 1998' (2014) 34 Oxford Journal of Legal Studies pp. 47-74, A Owusu-Bempah and M Walters Racially aggravated offences: when does section 145 of the Criminal Justice Act 2003 apply? 2016 Criminal Law Review 116, R Taylor 'the Role of the Aggravated Offences in Combating Hate Crime 15 Years After the Crime and Disorder Act 1998: Time for a Change?' (2014) 13 Contemporary Issues in Law 76. F Brennan 'Crime and Disorder Act 1998: racially motivated crime: the response of the criminal justice system' (1999) Criminal Law Review 17-28.
} 
will show how the discussion about the appropriate parameters of hate crime legislation must pay heed to the underlying rationale for such laws, and to the question of how their existence can be justified in accordance with basic criminal law values and principles. Hate crime laws in this country have their origins in provisions aimed at eliminating discrimination in order to ensure equality for all citizens. The concept of equality, therefore, lies at the heart of hate crimes laws, and so needs to form the focus of any discussion about the extension of hate crime legislation. The conceptual models traditionally used to define the parameters of hate crime legislation sit awkwardly with deeply held criminal law principles; however, it will be argued that the principle of equality may provide a theoretical framework for such statutes which is more easily accommodated within current criminal law structures. This will have inevitable implications for the category of victims which should be included in the law. Essentially, it will be contended that the inextricable link between the underlying justification for hate crime and the broader equality agenda means that the parameters of hate crime victims should mirror the characteristics covered by equality legislation, and any extension beyond this will throw into doubt the legitimacy of hate crimes. The article will end by discussing some of the implications of establishing a link between the equality agenda and hate crime legislation.

\section{The Victims of Hate Crime and the Principles of the Criminal Law}

It has been argued by some, such as Blake, that the decision as to which victims to include in hate crime legislation is purely policy-based. ${ }^{24}$ However, the current dispute over the victims of hate crime suggests that the disagreement goes beyond policy, and is in fact part of a much wider debate about the underlying rationale for hate crime legislation. If, for example, you take the view that the victims of hate crime law should include all 'vulnerable' groups, this suggests an entirely different notion about the purpose of hate crime than the view that 'group hostility' is

${ }^{24}$ M Blake, 'Geeks and monsters: Bias crimes and social identity' (2001) 20 Law and Philosophy 121. 
the core of hate crime..$^{25}$ The former suggests that hate crime laws are there to protect those who are vulnerable in society, whereas the latter implies that the purpose of hate crime law is to outlaw group-based hostility. These are fundamentally distinct conceptions of the rationale for hate crime legislation that cannot be dismissed as being purely policy-based, and reveal a far deeper schism amongst hate crime commentators. Thus, the dispute about who the victims of hate crime law should be is inextricably linked to the wider debate about the proper rationale for hate crime law. This section seeks to explore this question from a doctrinal perspective to explore whether the theoretical underpinnings of the criminal law can shed any light on the debate.

The first section will identify which principles of the criminal law are most problematic for hate crime legislation. The challenges posed by these principles must be overcome if a proposed rationale for hate crime legislation is to be deemed legitimate. The second section will consider to what extent 'vulnerability', 'group hatred' and 'disadvantage' can meet these challenges. The third section will argue that the concept of 'equality' is more consistent with these criminal law principles, and thus provides a more suitable rationale for hate crime legislation.

\section{(a) The Rationale for Hate Crime Legislation and the Principles of the Criminal Law}

To begin with, it is important to identify two important principles of the criminal law that pose a particular challenge for hate crime law. An analysis of these principles, and how they apply to hate crime legislation, will demonstrate that in order for a rationale for hate crime law to be

\footnotetext{
${ }^{25} \mathrm{~N}$ Chakraborti and J Garland, 'Reconceptualizing hate crime victimization through the lens of vulnerability and "difference"' (2012)16 Theoretical Criminology 499 and J Schweppe 'Defining characteristics and politicizing victims: A legal perspective' (2012) 10 Journal of Hate Studies 173.
} 
legitimate, it needs to be able to justify why hatred ${ }^{26}$ against specific groups should attract a greater punishment than the same offence committed without the hatred.

First, when the state proposes the creation of a new piece of legislation, it needs to be demonstrated that there is a strong case in favour of using the criminal law to prohibit such behaviour. Traditionally, J.S. Mill's notion of 'harm' has been used as a guiding principle for determining the legitimacy of a proposed law. ${ }^{27}$ In general terms, this stipulates that the criminal law should only be used to prohibit behaviour if that behaviour can be shown to cause 'harm' to others. ${ }^{28}$ Mill's 'harm' principle has been subjected to a number of criticisms and modifications over the years, but has had enduring appeal for many contemporary legal philosophers. ${ }^{29}$ By contrast, legal moralists believe that a necessary (although not sufficient) condition for criminalisation is that the underlying behaviour which the law aims to prohibit is morally 'wrong' ${ }^{30}$ Within both schools of thought, views differ as to the essential qualities of 'harm' or 'wrongness', ${ }^{31}$ but for our purposes, what this debate demonstrates is the need to articulate clearly the underlying 'harm' or 'wrong' which legislation seeks to outlaw. ${ }^{32}$

The second principle which needs to be examined is that of 'minimum criminalisation'. 33 The 'minimalist' approach to the criminal law requires that certain limits are imposed on the

\footnotetext{
26 The term 'hatred' is used in this article although it is acknowledged that the CDA offences use the word 'hostility'. 27 J S Mill, On Liberty and Other Essays (OUP, 1991). 1985), Volume 3: Harm to Self (OUP 1986), Volume 4: Harmless Wrongdoing (OUP 1990), H L A Hart, Law, Liberty and Morality (Stanford University Press 1963), A P Simester and A von Hirsch, Crimes, Harms, and Wrongs: on the principles of criminalisation (Hart 2011) and J Gardner and S Shute, "The Wrongness of Rape" in J Gardner, Offences and Defences (OUP 2007). For a summary, see J Edwards, 'Harm Principle' (2014) 20 Legal Theory 253.

${ }^{30}$ As with adherents of the 'harm' principle, proponents of legal moralism cover a broad range of viewpoints. Examples of legal moralists include P Devlin, The Enforcement of Morals (OUP 1965), M S Moore, Placing Blame: a general theory of the criminal law (OUP 1997), S E Marshall and R A Duff, "Criminalization and Sharing Wrongs" (1998) 11 Canadian Journal of Law and Jurisprudence 7; R A Duff, Punishment, Communication and Community (OUP 2000). ${ }^{31}$ For example, J Gardner and S Shute, "The Wrongness of Rape" in John Gardner, Offences and Defences (OUP 2007); and M S Moore, Placing Blame: a general theory of the criminal law (OUP 1997) and R A Duff, Punishment, Communication and Community (OUP 2000).

${ }^{32}$ For a more in depth discussion of this question, see J Stanton Ife 'Criminalising Conduct with Special Reference to Potential Offences of Stirring Up Hatred Against Disabled or Transgender Persons' in Law Commission, Hate Crime: The Case for Extending the Existing Offences (Consultation Paper 213).

33 A Ashworth and J Horder, Principles of the Criminal Law (7th edn OUP 2013) 31-35 and 52.
} 
boundaries of the criminal law. Commentators disagree as to what the proper limits of the criminal law should be, and various theories on criminalisation have been put forward. ${ }^{34}$ For the purposes of this discussion, one element from Douglas Husak's ${ }^{35}$ theory stands out as being of relevance to hate crimes. Husak puts forward several principles which should be used to determine the justifiability of a new law. ${ }^{36}$ One of these, is the need for the wrong that the law seeks to outlaw to be aimed 'toward a substantial state interest'. ${ }^{37}$ Husak suggests that the 'expressive' function ${ }^{38}$ of the law is a legitimate state interest. The 'expressive' function of the law is to send a clear message to the community about the wrongfulness of the conduct that is prohibited. However, Husak argues that this expressive function can only be legitimate and sufficiently important in the context of hate crime laws if 'arguments can be produced to show why crimes motivated by hatred are worse than those motivated by other emotions such as greed, or jealousy. ${ }^{39}$

It is necessary to consider the implications of both these principles for hate crime legislation. Although both principles apply to all three hate crime statutes, this discussion will focus on the CDA aggravated offences for three main reasons. Firstly, unlike the sentencing offences or the incitement to hatred offences, these provisions fall very clearly into the category of 'overlapping' offences that Husak identifies as being a particular characteristic of overcriminalisation. ${ }^{40}$ This is where behaviour that is already criminal is re-criminalised under a new statute with a more serious punishment. The aggravated offences essentially create new, more

\footnotetext{
${ }^{34}$ For a general discussion, see A Ashworth and J Horder, Principles of the Criminal Law (7th edn OUP 2013) 31-35 and 52 and R A Duff, L Farmer, S E Marshall, M Renzo and V Tadros, The Boundaries of the Criminal Law (OUP 2010). For more specific theories see D Husak, Overcriminalization, (OUP 2008) and J Schonscheck, On Criminalization (Kluwer Academic Publishers 1994); H Packer The Limits of the Criminal Sanction (Stanford University Press 1968) and S Kadish 'The Crisis of Overcriminalization' (1967) 74 Annals of the American Academy of Political and Social Science 157.

${ }^{35}$ D Husak, Overcriminalization (OUP 2008)

${ }^{36}$ For critiques of Husak's theory see, for example, P Ramsay, 'Overcriminalization as Vulnerable Citizenship' (2010) 13 New Criminal Law Review 262 and M Gur-Ayre, 'Comments on D Husak's Overcriminalization' (2010) 1 Jerusalem Review of Legal Studies 21. See also (2009) 28 Criminal Justice Ethics for a selection of papers discussing Husak's theory.

${ }^{37}$ D Husak, Overcriminalization (OUP 2008) 132.

${ }^{38}$ First put forward by J Feinberg Doing and Deserving (Princeton University Press 1970).

${ }^{39}$ D Husak, Overcriminalization (OUP 2008) 141.

${ }^{40}$ D Husak, Overcriminalization (OUP 2008) 132, 36-37
} 
serious offences where the offender has committed the basic offence whilst motivated by or demonstrating hostility towards the victim on the grounds of race or religion. ${ }^{41}$ Given that the underlying conduct of the CDA provisions are already criminalised, this means that considerable thought needs to be given as to the justification for the existence of these additional offences. This will necessitate a clear articulation of the extra harm or wrong being outlawed, and, in order to satisfy Husak's theory of criminalisation, to also explain why the motivation or demonstration of hostility is more harmful than if the conduct had been motivated by or demonstrated some other emotion. A second reason why this article will focus on the CDA offences is because they are the hate crime provisions which have attracted the most debate in the literature. ${ }^{42}$

Furthermore, the Law Commission has recently recommended a comprehensive review of the CDA to determine whether the aggravated offences should continue to exist and in what form. ${ }^{43}$ A serious consideration of the doctrinal legitimacy of these offences is, therefore, vital as part of this broader discussion. Finally, it should be noted that the CDA provisions are also the most widely prosecuted of our hate offences. According to CPS data, there were 13,032 prosecutions in 2015/16 for racially aggravated and religiously aggravated hate crimes under the CDA offences. In the same period, there was only one prosecution under the incitement offences. ${ }^{44}$ The CDA offences are also more extensively used than the enhanced sentencing provisions. ${ }^{45}$ Thus, it appears that whilst the CDA provisions form the bulk of our hate crime prosecutions,

\footnotetext{
${ }^{41}$ The recent Court of Appeal decision in O'Leary (Michael Patrick) [2015] EWCA Crim 1306 has clarified that there is an overlap between the CDA offences and the sentencing provisions under the CJA. For a discussion see A Owusu-Bempah and M A Walters 'Racially aggravated offences: when does section 145 of the Criminal Justice Act 2003 apply?' (2016) 2 Criminal Law Review 116 and R Taylor 'the Role of the Aggravated Offences in Combating Hate Crime 15 Years After the Crime and Disorder Act 1998: 'Time for a Change?’ (2014) 13 Contemporary Issues in Law 76.

42 See for example M. Malik, "'Racist Crime’: Racially Aggravated Offences in the Crime and Disorder Act 1998 Part II"(1999) 62 M.L.R. 409 and F. Brennan "Crime and Disorder Act 1998: racially motivated crime: the response of the criminal justice system" [1999] Crim. L.R. 17, D. Gadd, "Aggravating Racism and Elusive Motivation" (2009) 49 Brit. J. Criminology 755; Ormerod, Commentary at [2009] Crim. L.R. 449.

${ }^{43}$ Law Commission Hate Crime: Should the Current Offences be Extended? (HMSO, 2014), Law Com. No.348.

${ }^{44}$ CPS 'Hate Crime Report 2014/15 and 2015/16’ July 2016

45 There is very little data on enhanced sentencing. In fact, the UK was criticised for this in the most recent report by ECRI (European Commission against Racism and Intolerance) 'ECRI Report on the United Kingdom (fifth monitoring cycle)' 2016, 9. As the report points out, the assumption is that the enhanced sentencing provisions are under-used (p. 26)/
} 
they are also the ones which are most vulnerable to doctrinal attack, and so they require particular attention.

Identifying the 'harm' or 'wrong' in hate crime legislation has been discussed by commentators. ${ }^{46}$ Generally speaking, the debate in this area has seen a division between on the one hand those who believe the justification for this greater punishment lies with the greater blame we can attach to the offender because of their more blameworthy mens rea and, on the other hand, those who believe it lies with the more serious actus reus inherent in hate crimes. Broadly speaking, those who categorise hate crime as more serious because of the mens rea are essentially arguing from a legal moralist perspective (hate crime is 'wrong'), whilst those who argue that the greater blameworthiness lies in the actus reus correlate more closely with Mill's 'harm' principle (hate crime causes more 'harm').

Amongst those who believe that the justification for greater punishment lies in the more serious mens rea of the hate crime offender, a lively debate has been sparked about what makes a hate crime offender's state of mind more blameworthy. Lawrence, ${ }^{47}$ an early advocate of hate crime legislation, put forward a conceptual model for understanding the essential quality of the more seriously criminal state of mind. He proffered the view that it could either be the animus (or hatred) the offender feels towards the victim which justifies the harsher punishment, or it could be the fact that the offender showed bias in their selection of victim, even if this selection was not underpinned by a visceral or even passive hatred of the victim. ${ }^{48}$ Commentators have disagreed about which of these should form the proper conception of mens rea. ${ }^{49}$ However, even if a consensus could be reached as to whether it should be animus or bias that underpins hate crime legislation, the principle of minimum criminalisation as evinced by Husak would elicit the

\footnotetext{
46 See for example, F M Lawrence Punishing Hate: Bias Crimes Under American Law (Harvard University Press 1999) 73-79; L Wang, 'Recognizing opportunistic bias crimes' (2000) 80 Boston ULR 1399.

${ }^{47}$ F M Lawrence Punishing Hate: Bias Crimes Under American Law (Harvard University Press 1999).

${ }^{48}$ F M Lawrence Punishing Hate: Bias Crimes Under American Law (Harvard University Press 1999) 29-39.

${ }^{49}$ F M Lawrence Punishing Hate: Bias Crimes Under American Law (Harvard University Press 1999) 73-79 who preferred the animus model and Wang who prefers a discriminatory selection model: L Wang 'Recognizing opportunistic bias crimes' (2000) 80 Boston ULR 1399.
} 
further question of why it is appropriate to punish more for this state of mind, given that the basic offence under the CDA is already a criminal offence. In other words, why is acting out of animus or bias more serious than acting out of, for example, jealousy, or greed, or sadism? Goodall has developed (in the context of racist offences) a third category of mens rea which she refers to as 'constitutive animus. ${ }^{50}$ This defines the more blameworthy mens rea as requiring proof of individual moral culpability for the hostility the defendant has displayed against those of a different race. This is to be the key test of blame, rather than focusing only on effect, or only on whether the hostility was long-standing or fleeting. The prosecution must prove either that the defendant intended the act to have a racist effect or that $\mathrm{s} /$ he showed utter disregard for whether it might. The 'constitutive animus' model comes much closer to justifying hate crime legislation, but even if we take constitutive animus as our base point, it is still necessary to show why racism is a particular heinous state of mind that deserves extra punishment. Therefore, from a doctrinal point of view, in the context of the CDA provisions, even if the wrong of hate crime is determined as lying in the more blameworthy mens rea of the defendant, Husak's minimalist approach requires an explanation for why this wrong should be punished over and above the underlying basic offence. Thus, from the point of view of justifications based on mens rea, what is required is not only a description of what the more culpable mens rea is, but an explanation for why that additional mens rea should be criminalised.

Some hate crime scholars have preferred instead to situate the justification for hate crime legislation in the actus reus of the offence. Their argument is that the harm caused by hate crime is greater than the harm caused by offences committed without hate. ${ }^{51}$ There is a range of views as to what this extra harm is: some suggest that victims of hate crime are more adversely affected by a crime perpetrated against them because of their race or religion than victims of

\footnotetext{
${ }^{50}$ K Goodall, 'Conceptualising “racism” in the Criminal Law' (2013) 33 Legal Studies 215.

51 The greater harm caused by hate crimes is at the heart of Lawrence's justification for bias crimes, see F M Lawrence Punishing Hate: Bias Crimes Under American Law (Harvard University Press 1999) 39, 58 and 61-63. See also P Iganski, Hate Crime and the City (Policy Press 2008) ch 1 and P Iganski 'Hate Crimes Hurt More' (2001) 45 American Behavioral Scientist 626.
} 
more 'ordinary' crimes not involving such a motive; some argue that a hate crime has an impact beyond the direct victim, because it also affects other people who belong to that group; whilst others argue that hate crime has a greater impact on the whole of society than ordinary crime. ${ }^{52}$

However, whichever categorisation of 'harm' is adopted, the problem with a justification based on greater harm is that it cannot account for the form that hate crime legislation has taken under the CDA. There are two stages involved in the assessment and punishment of a defendant: the trial stage (or the liability stage), and the sentencing stage. Under basic criminal law principles, the point at which a defendant's guilt is assessed is during a trial at the liability stage, and this part of the criminal justice process is concerned with the blameworthiness of the individual defendant. Greater blameworthiness (whether of mens rea or actus reus) is reflected in the definition of an offence and in the greater maximum penalty. For example, although most burglaries are at heart cases involving theft, the additional and separate harm present in burglary cases in the form of trespass to the victim's property is reflected in the higher maximum penalty available for burglary in comparison to theft. ${ }^{53}$ The higher maximum penalty for burglary is justified by reference to the additional and separate type of harm caused in burglary cases by the trespass on the victim's property; and the existence of this separate type of harm is assessed at the liability stage. Meanwhile, the sentencing stage of the criminal justice process is more concerned with matters relating to the level of harm caused to the victim or society more generally. For instance, factors which aggravate the offence of theft (such as, for example, the value of goods stolen) are dealt with at the sentencing stage and not the liability stage. ${ }^{54}$

Applying this analysis to hate crimes, if we were to accept that hate fuelled incidents cause more harm to individual victims and/or to the communities they represent, this extra harm

\footnotetext{
52 See H M Hurd and M S Moore, "Punishing Hatred and Prejudice" (2004) 56 Stanford Law Review 1081,10851093 for a comprehensive discussion of the different ways in which the harm caused by hate crimes has been categorised.

53 Theft is punishable with up to seven years' imprisonment (Theft Act 1968, s. 7) whilst the highest maximum penalty for burglary is fourteen years' imprisonment (Theft Act 1968, s. 9(3)(a).

${ }^{54}$ Sentencing Council Theft Offences Definitive Guidelines (2015) 5.
} 
should be dealt with at the sentencing stage and not at the liability stage. This is because the harm caused by hate crimes is of the same type as that which occurs in the basic offences, but at a greater level because of the amplification effect of the hate. Hence, studies which show the extra harm caused to victims by hate crimes might provide a good justification for punishing offenders more at the sentencing stage, but they do not provide a sufficient explanation for why new aggravated offences are required which place extra blame on the defendant at the liability stage. In order, therefore, for a justification of CDA-style hate crimes based on actus reus to be successful it must be shown that the type of harm caused by hate crimes is of a different nature to that of the basic offences and is not simply a case of a differing level of harm.

To summarise, it seems, therefore, that as far as basic principles of the criminal law are concerned, the rationales put forward so far for the existence of CDA-like offences based on mens rea and actus reus are not sufficient to justify the extra punishment which these offences attract. In order for these explanations to be able to fully account for the aggravated offences, more is needed:explanations based on mens rea must be able to explain why a particular state of mind should attract more punishment than other states of mind; whilst explanations based on actus reus must show that the harm caused is of a different type of harm to that of the underlying basic offences.

\section{(b) Vulnerability, Difference, Group Hatred, Disadvantage and the Principles of the}

\section{Criminal Law}

It is apparent, therefore, from this discussion that a satisfactory explanation for the existence of hate crimes cannot be found simply by describing what the harm caused is or what the more serious state of mind is. Instead, what is required is an explanation that can delineate the boundaries of the offence more accurately, and can articulate why the 'harm' or 'wrong' is one 
that should be punished by the criminal law. This section will consider to what extent current explanations for hate crime victimhood correlate with these principles of the criminal law.

An example of a theory of victimhood based on the greater actus reus caused by hate crimes is that propounded by Chakraborti and Garland. They rgue that instead of putting identity and group membership at the heart of hate crimes, we should instead be focusing on the 'vulnerability' of victims, and the problems of 'difference'. They wish to step away from the traditional notion of hate crime because it singles out some groups for protection, and creates hierarchies of hate. ${ }^{55}$ This sends the message that some groups are more worthy than others, and that hatred of some groups is more acceptable than others. They believe that the approach based on a 'singular conception of identity ${ }^{56}$ is flawed because it fails to account for crimes committed against victims, such as the homeless, who may not fall into the traditional core groups usually protected by hate crime legislation. These groups may be marginalised, but they do not have the ability or impetus to make their presence felt at the policy level and so cannot gain recognition as a protected group.. Chakraborti and Garland are also critical of the traditional approach which identifies an exclusive set of victims because they believe that this ignores the way in which most low-level hate crimes are perpetrated. They argue that most hate crimes are not the result of deep-seated hatred or prejudice, but rather are the outcome of impulsive reactions arising from triggers which are unique to each situation. ${ }^{57}$ They maintain that a focus on 'vulnerability' would capture more fully the incidents of hate crime perpetrated against those most at risk from prejudice, hatred and hostility. This is because vulnerability 'encapsulates the way in which many hate crime perpetrators view their target: as weak, defenceless, powerless or with limited capacity

\footnotetext{
${ }^{55} \mathrm{~N}$ Chakraborti and J Garland, 'Reconceptualizing hate crime victimization through the lens of vulnerability and "difference" (2012) 16 Theoretical Criminology 499.

${ }^{56} \mathrm{~N}$ Chakraborti and J Garland, 'Reconceptualizing hate crime victimization through the lens of vulnerability and "difference"” (2012) 16 Theoretical Criminology 499, 504.

${ }^{57} \mathrm{~N}$ Chakraborti and J Garland, 'Reconceptualizing hate crime victimization through the lens of vulnerability and "difference"” (2012) 16 Theoretical Criminology 499, 503.
} 
to resist. ${ }^{, 58}$ Thus, the core of their claim is that difference can make victims vulnerable, and thus it is vulnerability caused by difference (as opposed to vulnerability caused by something else) that should determine which groups should be given protection under hate crime legislation.

From the point of view of the doctrinal principles of the criminal law, using vulnerability brought about by difference is problematic given that the 'vulnerability' of the victim (in a broad sense) is already admitted as an aggravating feature in the sentencing process. This is because it is recognised that the level of harm caused to a vulnerable victim is greater than that experienced by a non-vulnerable victim. As was argued above, this is consistent with the purpose of sentencing which is to ensure that the punishment the defendant receives should reflect the level of harm he or she has caused. The vulnerability of the victim does not change the nature or type of harm that is caused, which is why is it more appropriately dealt with at the sentencing stage rather than the liability stage. A vulnerable victim of, for example, an assault, may well be more scared than a non-vulnerable victim, or the fact of the assault may cause more fear in other members of the public who share the same vulnerability as the victim, but the type of harm is the same harm albeit in an amplified form. Thus, rationales for hate crime based on the vulnerability of the victim caused by difference have difficulty explaining why the harm caused in the aggravated offences under the CDA are of a different type to the basic offences and which, therefore, warrants the harm to be included at the liability stage.

By contrast, although Schweppe also supports the need for a broader, more inclusive concept of hate crime, her theory of victimhood emphasises the greater blameworthiness or mens rea present in hate crimes. Under her approach, hate crime legislation would be flexible enough to allow juries to convict defendants if they believe 'that the motivation behind the criminal offence was based on hostility towards the victim...because of their personal characteristics (or presumed characteristics)... which he or she shares with an identifiable

${ }^{58} \mathrm{~N}$ Chakraborti and J Garland, 'Reconceptualizing hate crime victimization through the lens of vulnerability and “difference”" (2012) 16 Theoretical Criminology 499, 507. 
group. ${ }^{59}$ Although she suggests that equality legislation would be a good starting point for identifying victims of hate crime, her approach would go further and impose no restrictions on which groups could find protection under hate crime law. She advocates an approach like the one adopted in the Canadian legislation whereby a list of characteristics protected by hate crime legislation can be extended to include 'any other similar factor'. ${ }^{60}$ She argues that this would ensure that hierarchies of hate would not be created as virtually any social group could potential come within the definition of a hate crime.

By focussing on the idea of 'group hostility' Schweppe is closer to traditional notions of hate crime law as espoused, for example, by Perry. ${ }^{61}$ Schweppe attempts to explain the wrong caused by hate crime as the additional element of discrimination involved in the motivation of the offender. However, as far as Husak's theory of criminalization is concerned, this rationale for hate crime law still requires an explanation for why discrimination against a person because of the characteristics they share with a group is a sufficiently wrongful motivation - as opposed to motivations based on greed, or jealousy - to be given special attention by the law in the form of the aggravated offences. Whilst Schweppe's theory can give us a clear account of what hate crime legislation aims to do - punish discrimination based on group hostility - it does not give a normative explanation for this, particularly in the context of the principle of minimal criminalisation. This is because it does not explain fully why we need to punish people for their discriminatory motivation, and why this motivation justifies the existence of the CDA offences within the principles of minimum criminalisation.

The final theory on victim categorisation to be considered is Al-Hakim's contention that hate crime victims should be based on 'disadvantage'. ${ }^{62}$ He argues that 'disadvantage' is a more

\footnotetext{
${ }^{59}$ J Schweppe 'Defining characteristics and politicizing victims: A legal perspective' (2012) 10 Journal of Hate Studies 173, 187.

${ }^{60}$ section 718.2(a)(i) of the Canadian Criminal Code

${ }^{61}$ B Perry In the Name of Hate: Understanding Hate Crimes (Routledge 2001).

${ }^{62} \mathrm{M}$ Al-Hakim, 'Making a home for the Homeless in Hate Crime Legislation' (2014) Journal of Interpersonal Violence 1.
} 
useful way of allocating protection under hate crime legislation because it offers a better explanation for the link between the categories of victims commonly included in hate crime legislation. He argues that other explanations such as 'group hostility' or 'vulnerability' are overinclusive as they do not adequately capture the wrong that hate crimes attempt to proscribe. $\mathrm{He}$ reasons that adopting the politically neutral concept of 'disadvantage' that focusses on 'functioning' and 'capabilities' handicaps ${ }^{63}$ will ensure hate crime legislation will include the groups in society most deserving and in need of protection. Al-Hakim provides a cohesive and persuasive theorisation of the different groups that are currently included in hate crime legislation. His insight that the common denominator between these groups is 'disadvantage' is very valuable. However, much like Schweppe's ideas on victimhood, 'disadvantage' can only take as so far in relation to the theory of minimal criminalisation, as it cannot explain why 'disadvantage' should be given greater protection in the criminal law in the form of aggravated offences. Al-Hakim's theory may be helpful in determining which emerging groups ought to be included in hate crime legislation, but it presupposes that such protection is legitimate and fails to give an adequate justification for the aggravated offences.

Thus it can be seen that whilst there is a small but growing literature on which groups should be incorporated under hate crime laws, current explanations are not able to explain why the harm caused to the victims of hate crime warrants the existence of the CDA offences. Any description of victimhood must be able to explain what the additional harm or more blameworthy mens rea is in order to provide a legitimate rationale for aggravated offences.

\section{(c) Equality as the Basis for Hate Crime Offences}

\footnotetext{
${ }^{63} \mathrm{M}$ Al-Hakim, 'Making a home for the Homeless in Hate Crime Legislation' (2014) Journal of Interpersonal Violence 1, 20.
} 
Given the doctrinal weaknesses in the 'vulnerability', 'group hostility' and 'disadvantage' explanations for hate crime law, this section will argue that an equality-based conception of hate crime is able to provide a normative explanation for the criminalisation of hatred which is more consistent with the principles of the criminal law.

It is important at the outset to explain what is meant by the term 'equality'. 'Equality' has at times been used by commentators in the context of discussions about hate crime. However, the definition used by different commentators has varied. For example, for Perry, social and political inequalities are the explanation for why hate crime happens in the first place. She explains that hate crime:

“...is a means of marking both the Self and other in such a way to re-establish their 'proper' relative positions, as given and reproduced by broader ideologies and patterns of social and political inequality" 64

By contrast, Harel and Parchomovsky ${ }^{65}$ put equality at the centre of their argument by positing that the basis of hate crime legislation is the broader societal concern for the fact that certain groups are more vulnerable to attack. They argue that this means those groups need extra protection from the law in order to ensure equality of access to the criminal justice process. ${ }^{66}$ Thus, Harel and Parchomovsky use 'equality' as a way of justifying the existence of hate crime rather than as an explanation for why hate crimes occur. Like Harel and Parchomovsky, Lawrence also uses the broad concept of 'equality' as a general justification for bias crime. ${ }^{67} \mathrm{He}$ says:

${ }^{64}$ B Perry In the Name of Hate: Understanding Hate Crimes (Routledge 2001).10.

65 A Harel and G Parchomovsky 'On Hate and Equality' (1999) 109 Yale Law Journal 507.

${ }^{66}$ See H M Hurd and M S Moore, "Punishing Hatred and Prejudice" (2004) 56 Stanford Law Review 1081 for a criticism of this approach

${ }^{67}$ F M Lawrence Punishing Hate: Bias Crimes Under American Law (Harvard University Press 1999), 2,3, 8. 
"Because racial harmony and equality are among the highest values held in our society, crimes that violate these values should be punished more harshly than crimes that, although otherwise similar, do not violate these values." ${ }^{, 68}$

He takes a much broader view than Harel and Parchomovsky about what is meant by 'equality'. However, this concept is not developed further in Lawrence's book, and he chooses instead to focus on the greater harm caused by hate crimes to justify their existence. This piece will build on Lawrence's idea that the basis of hate crimes is the concept of equality by demonstrating that this core value has been enshrined in law through a vast array of equality legislation over a number of decades. It will be argued that the justification for hate crimes is linked to this legislation: offenders who target their violence towards groups who have already been identified as requiring the coercive power of the law to eradicate discrimination against them, risk destabilising social cohesion and perpetuating prejudices that threaten our society's ideals.

To begin with, in exploring the origins of hate crime legislation, the links with the broader equality agenda are unmistakeable. The first attempt to legislate against hatred formed part of the raft of provisions contained in the Race Relations Act 1965 (hereafter 'RRA') which sought to make discrimination on the basis of race unlawful. This Act was heralded as a watershed for race relations in Britain, and was introduced at a time when the pernicious effect and magnitude of racial discrimination had come into sharp focus following the wave of Caribbean and Indian immigration to this country in the 1950 's. ${ }^{69}$ The vast majority of provisions under the RRA 1965 were aimed at tackling the problem of racism through the civil law, particularly in relation to employment and the provision of services. There was, however, an accompanying criminal law measure under section 6 which made it a criminal offence to incite racial hatred. Subsequently, s. 6 underwent changes under s. 70 of the Race Relations Act 1976

\footnotetext{
${ }^{68}$ F M Lawrence Punishing Hate: Bias Crimes Under American Law (Harvard University Press 1999), 8 ${ }^{69}$ See G Schaffer, 'Legislating against Hatred: Meaning and Motive in Section Six of the Race Relations Act of 1965' (2014) 25 Twentieth Century British History for a history of the legislation.
} 
and then again under s. 18 and s. 19 of the Public Order Act 1986, but its origins very clearly lie in legislation aimed directly at outlawing discrimination.

Similarly, the aggravated offences under sections 28-32 of the Crime and Disorder Act 1998 were also introduced as a way of endorsing good race relations and clamping down on discrimination. ${ }^{70}$ The racially motivated offences enacted under the 1998 Act were based on proposals in a consultation document entitled Racial Violence and Harassment: A Consultation Document ${ }^{71}$ which cites a Home Affairs Select Committee which describes racial crime 'as the most shameful and dispiriting aspect of race relations in Britain'. ${ }^{72}$ This shows a clear link between the issue of race relations more generally and the criminal law, and paints a picture where racial violence is highlighted as a symptom of a much wider, social problem.

It is clear, therefore, that s.18 and 19 of the POA, and sections 28-32 of the CDA 1998, were advanced as a response to increasing ethnic diversity and division in Britain, and formed part of the growing governmental agenda addressing issues arising from multiculturalism. However, since the RRA 1965, anti-discrimination provisions and the broader multiculturalism agenda have undergone an extensive broadening out in so far as the protected characteristics are concerned. Whilst the RRA 1965 was the first of its kind and was subsequently followed by further race relations acts ${ }^{73}$ other movements were making political gains in parallel to those of race. ${ }^{74}$ For example, the gender equality movement, which had begun much earlier in the late $19^{\text {th }}$ century, was experiencing a 'second wave' momentum which led to the Equal Pay Act 1970, the Sex Discrimination Act 1975 (which resulted in the establishment of the Equal Opportunities Commission) and finally the introduction of the public sector gender equality duty

\footnotetext{
${ }^{70} \mathrm{~F}$ Brennan 'Crime and Disorder Act 1998: racially motivated crime: the response of the criminal justice system' (1999) Criminal Law Review 17-28.

${ }^{71}$ Paragraph 2.3 in Home Office Racial Violence and Harassment: A Consultation Document (1997) para 2.3.

72 Racial Attacks and Harassment (Session 1985-6) HC 409 cited in Home Office Racial Violence and Harassment: A Consultation Document (1997).

${ }^{73}$ Such as the Race Relations Act 1968 and the Race Relations Act 1976; See also Sandra Fredman, Discrimination Law (OUP 2011) 50-68.

${ }^{74}$ S Fredman, Discrimination Law (OUP 2011) Ch 2.
} 
under the Equality Act 2006. Meanwhile, the introduction of the Human Rights Act 1998 gave the gay rights movement the tools to challenge a number of laws which enabled it to achieve equality for sexual orientation in areas as diverse as the armed forces, adoption, succession and immigration. ${ }^{75}$ Groups supporting and protecting the rights of the disabled also gathered momentum in this period. ${ }^{76}$

By 2010, these parallel movements had generated a number of diverse pieces of legislation which had been introduced in a piecemeal fashion depending on the needs of the individual movements and the political opportunity to have their demands recognised within the law. This resulted in uneven protection being afforded to the different characteristics. However, despite their disparate interests, the clear link between the competing groups was the concept of equality: fundamentally all these groups were campaigning for equal recognition and status before the law. More broadly, these movements formed part of a wider multicultural agenda which sought to bring about community cohesion and to celebrate difference. This began with race, but came to include other groups who had historically found themselves disadvantaged politically, socially and legally. This idea of equality as the meeting point of these interest groups became entrenched under the Equality Act 2010 which brought together nine protected characteristics $^{77}$ and created a general public sector duty to eliminate unlawful discrimination, to advance equality of opportunity and to foster good relations between different groups. Thus, we are now in a position where, broadly speaking, the nine protected characteristics enjoy equal protection under the law.

Insofar as hate crime legislation is concerned, it can be seen that a similar expansion of the characteristics protected under the law is occurring. Whilst the CDA and POA were

\footnotetext{
75 S Fredman, Discrimination Law (OUP 2011) 86-93.

76 S Fredman, Discrimination Law (OUP 2011) 95-101.

77 Equality Act 2010, s 4: age, disability, gender reassignment, marriage and civil partnership, pregnancy and maternity, race, religion or belief, sex, sexual orientation.
} 
originally aimed at protecting race, these have been extended to religion and sexual orientation. ${ }^{78}$ The Ministry of Justice's brief to the Law Commission to consider extending all the offences to disability, sexual orientation and transgender fits in with this pattern of development and is mirroring the changes in equality law. ${ }^{79}$

Jacobs and Potter have traced a similar shape to the development of hate crime legislation in the United States and which they identify as part of the 'identity politics' movement. ${ }^{80}$ They have shown how various interest groups and minorities have gradually been included in hate crime legislation as their political importance has grown. This suggests that our own model of development is far from unique and represents a general trend in the advancement of hate crime law. Jacobs and Potter, however, are very cynical about the political motivation behind both the introduction of hate crime legislation and its expansion to include several minority groups. They believe that crimes of hatred are a relative rarity and therefore do not require tailored legislation. They argue that legislatures have opted to adopt such statutes anyway as a way of garnering favour with minority groups and to respond to a heightened public sensitivity towards prejudice. Their concern with the use of the criminal law for such symbolic purposes lies in the fact that:

'...hate crime laws encourage citizens to think of themselves as members of identity groups and ... as victimized and besieged... [which] contributes to the balkanization of American society, not its unification' ${ }^{81}$

Jacobs and Potter, therefore, believe that the 'identity politics' which hate crimes play up to has a pernicious effect on a cohesive society. McLaughlin has shown how this belief forms part of a larger debate within American political culture about how best to achieve an 'open society' which

\footnotetext{
78 The CDA offences were extended to 'religion' by the Anti-terrorism, Crime and Security Act 2001, s 39. The public order offences were extended to 'religion' by the Racial and Religious Hatred Act 2006, and to 'sexual orientation' by the Criminal Justice and Immigration Act 2008.

${ }^{79}$ Law Commission, Hate Crime: The Case for Extending the Existing Offences (Consultation Paper 213).

${ }^{80} \mathrm{~J}$ B Jacobs and K Potter, Hate Crimes: Criminal Law and Identity Politics (OUP 1998).

${ }^{81} \mathrm{~J}$ B Jacobs and K Potter, Hate Crimes: Criminal Law and Identity Politics (OUP 1998) 131.
} 
is free and equal for everyone. ${ }^{82}$ The debate centres on a disagreement about the ideal way to accommodate differences between people; some argue that the celebration and promotion of difference is the path to social cohesion, whilst others believe that drawing attention to such differences will ultimately exacerbate social tensions between groups. ${ }^{83}$ Jacobs and Potter are firmly of the opinion that highlighting difference will not solve the problem of a fragmented society, and this explains their reservations over the enactment of hate crime statutes. ${ }^{84}$ However, the types of concerns expressed by Jacobs and Potter have not held much sway in the multiculturalism debate in the UK where the general thrust of legislation, as evinced by the Equality Act 2010 and all the statutes preceding it, has been in favour of honouring difference and giving extra protection where necessary.

However, it is important to note that whilst the celebration of difference can be seen as a shared characteristic between the various groups which have gradually gained recognition within the equality legislation, a much more fundamental connection between them is the fact that these groups have historically been oppressed in one way or another, and hence require the strong-arm of the law to enable them to lead free and equal lives. This is a far more critical factor than that of difference because it explains why these groups have fought for recognition within the law rather than merely through cultural or social acceptance. There are other interest groups which have sought to promote the welfare of their members both through legal and non-legal means, ${ }^{85}$ but legal recognition has only been afforded to those groups for whom it is deemed a necessity. Equality lawyers have also sought to make this distinction and Solanke has argued that 'equality law is designed to address oppression rather than just promote diversity ${ }^{86}$ As such, protected characteristics do not simply represent groups which are 'different' in some way, but rather

\footnotetext{
${ }^{82}$ E MClaughlin, 'Rocks and hard places: The politics of hate crime' (2002) 6 Theoretical Criminology 493.

${ }^{83}$ E MClaughlin, 'Rocks and hard places: The politics of hate crime' (2002) 6 Theoretical Criminology 493, 496-7.

${ }^{84} \mathrm{~J}$ B Jacobs and K Potter, Hate Crimes: Criminal Law and Identity Politics (OUP 1998).

85 See $n$ 75-77 below.

86 I Solanke, 'Infusing the Silos in the Equality Act 2010 with Synergy' (2011) 40 Industrial Law Journal 336, 353.
} 
consists of groups which have also been systematically oppressed, and are at risk of unequal treatment within society without the added protection of the law.

Historically speaking, it is clear that hate crimes statutes have been seen as integral parts of the broader equality agenda. The link between oppression and the need for legal redress has also been made in the context of hate crime law. McLaughlin makes the point that the groups which have sought recognition under hate crime legislation are ones which are '.. historically subordinated' and have '...endured prejudice, harassment, and violence'. ${ }^{87}$ Perry's wellestablished definition of hate crime describes it as ' .... mechanism of power and oppression, intended to reaffirm the precarious hierarchies that characterise a given social order. ${ }^{, 88}$

However, as well as being of historical significance, an explanation based on equality has the additional advantage of being able to explain at a doctrinal level how hate crime law can be justified. For scholars who prefer to explain hate crimes on the basis of the more blameworthy men rea, equality is able to explain why hatred of certain groups is punished more severely than other motives: the hostility demonstrated towards certain groups is more blameworthy because it undermines the equality enterprise. From an actus reus point of view an explanation based on equality is able to show why hatred of specified groups causes a different type of harm to society that that of the underlying offence: the harm is the damage to equality which results from hateful behaviour. In this way, equality as the underlying rationale for hate crimes can serve as a doctrinal justification for the criminalization of hatred. It is able to articulate clearly and precisely what the additional harm or wrong involved in hate crime is, and is thus able to show how hate crimes can be appropriately accommodated within traditional criminal law structures. Furthermore, an equality-based conception of hate crime is able to provide a normative explanation for the criminalisation of hatred which is more consistent with the doctrine of minimum criminalisation as espoused by Husak. As was noted above, Husak stated that in order

${ }^{87}$ E MClaughlin, 'Rocks and hard places: The politics of hate crime' (2002) 6 Theoretical Criminology 493, 496.

${ }^{88}$ B Perry In the Name of Hate: Understanding Hate Crimes (Routledge, 2001) 10. 
for the expressive function of hate crime legislation to be legitimate, it is necessary to demonstrate that the hatred being outlawed by the provisions is more wrongful than other emotions such as jealousy or greed. Equality is a core value of society that has been enshrined in law by the state. By targeting violence towards groups who have already been identified as requiring the coercive power of the law to eradicate discrimination against them, hate crime offenders risk destabilising social cohesion and perpetuating prejudices that threaten our society's ideals. This provides a clear explanation for why hatred is singled out as a particularly heinous emotion, and why acts accompanied by hatred are more wrongful.

\section{Consequences of Adopting Equality Law as the basis of hate crime}

\section{legislation}

It follows from the previous discussion that certain consequences will ensue from adopting equality law as the basis of hate crime legislation.

Insofar as the question of how we should determine victimhood within hate crime legislation is concerned, it is clear that the protected characteristics as enunciated in the Equality Act 2010 should form the framework for hate crime legislation. If a characteristic has been deemed to be sufficiently persecuted or subjugated that it requires civil law protection under the Equality Act 2010 , then it is justifiable in principle to extend this protection through the criminal law.

However, although inclusion of the protected characteristics in hate crime legislation is legitimate in such circumstances, it does not follow that it is also appropriate or necessary. A further stage is required to determine whether the extra protection which results from recognition within the hate crime statutes is necessary. This is important as the principle of minimum criminalisation 
demands that a new criminal offence must only be created if necessary, and where non-legal methods cannot achieve the same purpose. ${ }^{89}$ The principle of equality is able to express the additional harm or wrong involved in hate crimes, and can, therefore, provide a reason for criminal sanctions and can account for the extra punishment inflicted on offenders. However, it does not tell us whether criminalisation is necessary. In the civil law, the decision whether or not to include certain characteristics may be based on evidence that there is discrimination in the workplace or in the provision of services on those grounds. In the Criminal Law, the assessment of the need for extra protection will depend on any evidence that these groups are indeed targeted by criminals on the basis of their particular characteristic so it is still important to ask this further question in order to safeguard the integrity of the principle of minimum criminalisation.

Viewing hate crime through the lens of equality in this way would, therefore, provide a very good basis for the review of the CDA offences as recommended by the Law Commission. ${ }^{90}$ Currently, the CDA provisions do not include sexual orientation, disability and transgender identity. However, if there is evidence that these groups are suffering targeted violence (and clearly there is), then the fact that these characteristics are covered in the equality legislation would be a prima facie reason for extending the CDA provisions. This analysis would also pave the way for feminist groups to argue that gender should also be included within hate crime legislation. ${ }^{91}$

An inevitable consequence of limiting the victims of hate crimes to the protected characteristics under the Equality Act 2010 is that some vulnerable groups, such as the homeless or members of the goth community, will not be covered by the legislation. This will indeed create 'hierarchies of hate' as pointed out by some commentators, as the message will be that

\footnotetext{
${ }^{89}$ A Ashworth and J Horder, Principles of the Criminal Law (7 $7^{\text {th }}$ edition OUP 2013) 33; see also Jonathan Schonscheck, On Criminalization (Kluwer Academic Publishers 1994) for a discussion of a 'filtering process' that determines when it is appropriate to use the criminal law to prohibit conduct.

${ }^{90}$ Law Commission Hate Crime: Should the Current Offences be Extended? (HMSO, 2014), Law Com. No.348.

${ }^{91}$ See for example discussion in M Walters and J Tumath 'Gender 'hostility', rape and the hate crime paradigm' (2014) 77 Modern Law Review 563.
} 
committing crimes against certain groups will be punished more harshly than crimes against other groups. ${ }^{92}$ Indeed, it could be said that the equality argument creates a paradox: if, as is argued here, hate crimes are about 'equality' how can we justify the unequal treatment of victims that this entails? This is a valid question and can be addressed in three ways.

Firstly, this issue has been dealt with in great depth in the equality literature which suggests that the solution may be found in the distinction between formal and substantive equality. ${ }^{93}$ Formal equality requires all citizens to be treated in the same way irrespective of their personal characteristics. This vision of equality would not countenance the existence of hate crime laws for the precise reason in the question posed above - hate crime legislation applies different rules depending on who the victim is, and so it breaches the rules of formal equality. However, a broader conception of equality which underpins modern equality legislation, ${ }^{94}$ and, as is argued in this piece, by implication hate crime legislation, is that of substantive equality, and more precisely equality of opportunity. This substantive concept of equality recognises that historical discrimination means that not all groups in society have been given the same starting point, and so, legislation is required to even the playing field to ensure all groups are given the same opportunities. ${ }^{95}$ This will often require certain disadvantaged groups to be treated differently by the law in order to ensure equality of opportunity. In the context of hate crime legislation, this concept of equality explains why hate crime law is justified in giving more protection to certain groups: in order to ensure the groups recognised under equality legislation enjoy the same opportunities as others, targeted violence against them needs to be treated more harshly. This sends a clear message that this behaviour is particularly harmful to society because it undermines the equality of opportunity that these groups deserve and which equality legislation seeks to secure.

\footnotetext{
${ }^{92} \mathrm{~N}$ Chakraborti and J Garland, 'Reconceptualizing hate crime victimization through the lens of vulnerability and "difference" (2012) 16 Theoretical Criminology 499

93 Sandra Fredman, Discrimination Law (OUP 2011) 8-14

${ }^{94}$ Sandra Fredman, Discrimination Law (OUP 2011) Chapter One

${ }^{95}$ Sandra Fredman, Discrimination Law (OUP 2011) 18-19
} 
A second way of answering this question is to distinguish here between what is the essential function of hate crime legislation on the one hand, and, on the other, the inevitable operational benefits of being an included group. The essential function of hate crime legislation is the expressive element which is the recognition of the different type of harm or wrong caused by the perpetrators of hate; it is a statement by society that violence targeted at protected characteristics is particularly harmful or wrong, and therefore worthy of greater punishment, because it undermines the core value of equality as enshrined in the Equality Act 2010. The operational benefit of hate crime legislation is that it can increase the likelihood that the police and the CPS are more alert to the needs of that particular community, and means that arrests and prosecutions are more likely. These operational benefits are very important, but given that violence against anyone is already a criminal offence, creating legislation in addition to existing offences would be violating the doctrine of minimum criminalisation if this were done for the sole purpose of drawing the police's attention to crimes committed against certain groups ${ }^{96}$ In order to secure the doctrinal legitimacy of hate crimes, the inevitable consequence of this is that not all groups who wish to avail themselves of the operational benefits of hate crime will be able to be included in the legislation.

A third issue to highlight here is the fact that the alternative option - an open, or inclusive category of hate crime victims - is not an attractive solution. Firstly, concerns have been expressed about the potential dilution effect of hate crime legislation if it is applied to a large number of characteristics. ${ }^{97}$ It has been argued that dilution can happen both in terms of reducing the power of the message put across by the legislation that hate crimes are particularly heinous, but also in terms of the operational burden for the police and the CPS if their limited resources are spread across too many groups. Chakraborti and Garland argue that the operational burden is vastly overrated, and the police and the CPS would be able to cope with

\footnotetext{
${ }^{96}$ A Ashworth and J Horder, Principles of the Criminal Law (7 $7^{\text {th }}$ edn OUP 2013), 33; D Husak, Overcriminalization (OUP 2008), 77-91.

${ }^{97}$ Nathan Hall, Hate Crime (Routledge 2013).
} 
this. ${ }^{98}$ However, even if we set aside the operational arguments, it is still necessary to consider in more detail the argument relating to the dilution of the message that hate crimes communicate. As the law currently stands, the CDA offences treat hate crimes more severely not because we consider the motivation or demonstration of hostility an aggravating factor, but because we consider the hostility felt towards particular characteristics as an aggravating factor. If the categories of victim were not specified, and instead were potentially limitless and at the discretion of the jury or a judge, this would fundamentally change the essence of hate crime legislation and distort its message. This is because inconsistencies will inevitably creep into the law with some groups being given recognition under the legislation some of the time, but not at others. These discrepancies will undermine the fundamental aim of hate crime legislation which is to draw attention to the particularly serious nature of certain behaviour; if the seriousness of the behaviour is left to the vagaries of discretion (whether of judges or juries), it is difficult to see how effective the message of hate crime can be. It will no longer be the case that hatred against a group is always more serious, but rather it might be depending on whether the judge or jury decide it is in that particular case.

A corollary to the argument about hierarchies of hate is that some offenders will be punished more than others. This is potentially problematic in the context of hate crimes. Perry has shown how offenders of hate crime are often themselves victims of social inequality; ${ }^{99}$ and Lamble has noted the way in which progressive groups, such as the LGBT community which was once a target of police abuse, now use the politics of incarceration and policing as a way of furthering their movement's goals. ${ }^{100}$ It could, therefore, be argued that punishing those who are themselves victims of inequality in the interests of the broader equality agenda does not make

\footnotetext{
${ }^{98}$ Neil Chakraborti and Jon Garland, 'Reconceptualizing hate crime victimization through the lens of vulnerability and "difference"” (2012) 16 Theoretical Criminology 499, 508.

${ }^{99}$ B Perry In the Name of Hate: Understanding Hate Crimes (Routledge 2001).

- $\quad{ }^{100} \mathrm{~S}$ Lamble 'Queer necropolitics and the expanding carceral state: interrogating sexual investments in punishment'. (2013) 24 Law and Critique
} 
sense. The strength of this argument lies in giving us pause for thought when considering the best way of punishing hate crime offenders. It may well be that this suggests that alternatives to imprisonment, such as restorative justice,${ }^{101}$ should be considered in the context of hate crime. However, it is not an argument for avoiding the additional punishment altogether. This would be akin to saying, for example, that someone who has been a victim of violence should not be punished for committing acts of violence themselves. Without doubt legislating for hate crime will not be a panacea all for social inequality. However, recognising the harm caused by hate crime to social cohesion will bring us one step closer to eradicating bias and prejudice that is divisive and destructive.

\section{Conclusion}

The choice over which groups should have protection under hate crime legislation is not purely a political or policy-based one whereby only those with the necessary resources to bring themselves to the attention of the state are given recognition. In fact, the decision is inextricably linked to the underlying rationale for hate crimes. This is because the principles we use to determine the categories of victims reflect our core beliefs about the values at the heart of hate crime legislation. Various suggestions have been put forward as to how we can determine these values, and subsequently how we can choose our categories of victims. Concepts such as 'vulnerability' or 'group hostility' or 'disadvantage' have been argued to be at the centre of hate crime legislation.

This article argues that in order for a rationale of hate crime law to be valid, it needs to accord with basic principles of the criminal law. Two such principles were considered in more detail: first, the need for a clear articulation of the 'harm' or 'wrong' that hate crime are designed to

${ }^{101} \mathrm{M}$ Walters Hate crime and restorative justice: exploring causes, repairing harms (OUP 2014) 
outlaw, and secondly the need to ensure the principle of minimum criminalization is adhered to. It was argued that using 'equality' as enshrined in equality legislation not only gives a historic account for the development of hate crime legislation, but also provides a more principled basis for understanding the 'wrong' or 'harm' at the centre of hate crimes. The concept of equality is better able to explain adequately Husak's requirement that hate crime legislation must justify why 'hate' is punished more severely than other emotions. This is because it explains that the additional 'harm' or 'wrong' committed by perpetrators of hate crime is the destabilising of social cohesion and the perpetuating of prejudices that threaten our society's ideals. This argument necessarily requires the victims of hate crime to be linked to the protected characteristics under equality legislation, and will, therefore, result in an exclusive group of victims. It is argued, however, that this will not necessarily result in unequal protection to vulnerable victims if the operational and expressive functions of hate crime legislation are de-coupled. 